\title{
Mainland Chinese and Japanese Tourists in Taiwan: The Travel Mode and Shopping Expenditures
}

\author{
Jie-Min Lee1, Li-Ming Ho², Chun-Yuan Yeh³, Christian Schafferer ${ }^{3}$ \\ ${ }^{1}$ Department of Shipping and Transportation Management, National Kaohsiung Marine University, Taiwan \\ ${ }^{2}$ Department of Marine Leisure Management, National Kaohsiung Marine University, Taiwan \\ ${ }^{3}$ Department of International Trade, Overseas Chinese University, Taiwan \\ Email: jmlee866@yahoo.com.tw, ^lmhonkmu@gmail.com, iune@ocu.edu.tw, chris@ocu.edu.tw
}

How to cite this paper: Lee, J.-M., Ho, L.-M., Yeh, C.-Y. and Schafferer, C. (2017) Mainland Chinese and Japanese Tourists in Taiwan: The Travel Mode and Shopping Expenditures. Open Journal of Social Sciences, 5, 100-118.

https://doi.org/10.4236/jss.2017.511008

Received: October 27, 2017

Accepted: November 25, 2017

Published: November 28, 2017

Copyright $\odot 2017$ by authors and Scientific Research Publishing Inc. This work is licensed under the Creative Commons Attribution International License (CC BY 4.0).

http://creativecommons.org/licenses/by/4.0/

\begin{abstract}
This paper uses quantile regression to investigate the travel mode and the shopping expenditures of over 7000 Chinese and Japanese tourists interviewed as part of the 2012-2013 Annual Survey Report on Visitor Expenditures and Trends in Taiwan. Results show that most Chinese tourists prefer to travel in group package tours, whereas most Japanese tourists prefer to travel independently. Both Chinese and Japanese tourists traveling in package tours purchase considerably more than individual travelers. Chinese visitors with high disposable income who travel in group tours had the highest shopping expenditures. Travelers over 40, those with college education or with higher income, and females had higher shopping expenditures than tourists in other demographics. Consequently, promotional marketing campaigns focusing on these travel segments could lead to significant increases in consumption and thus benefit Taiwan's tourism industry and economy.
\end{abstract}

\section{Keywords}

Group Package Tour, Travel Mode, Shopping Expenditures, Foreign Independent Tour, Quantile Regression

\section{Introduction}

Tourism is one of Taiwan's most important industries. According to the Taiwan Tourism Bureau, 9.9 million international tourists visited Taiwan in 2014-an increase of 1.9 million visitors over 2013 [1]. Total foreign exchange income from tourism reached US $\$ 12.3$ billion in 2013 , an increase of $4.7 \%$ from the 
previous year [2] [3]. The largest number of international visitors came from China $(3,987,152)$, and the second largest number from Japan $(1,634,790)$. It is predicted that Chinese tourists will spend a record 793 billion Chinese Yuan Renminbi (CNY) in Taiwan by 2017 and that the total number of Chinese tourists visiting Taiwan will reach 200 million by 2020 [4].

Several studies have shown that shopping is one of the prime reasons people choose to travel [5]-[11], as well as one of the major activities undertaken by tourists during their travels [12]. Japanese and Chinese tourists are reported to be comparatively more interested in shopping and have higher shopping expenditures than travelers from other countries [13] [14] [15]. However, spending patterns between Chinese and Japanese tourists differ considerably. According to Taiwan's Tourism Bureau [2], visitors from Japan predominately purchase local specialty products (58.32\% of all expenditures), whereas visitors from China are more inclined to purchase jewelry or jade articles (33.66\%) and local specialty products $(22.31 \%)$. Studies have also shown that Chinese tourists put greater emphasis on service quality and expect excellent cultural understanding of their wants and needs [16]. They also tend to pursue top brand name goods, and view traveling to famous destinations as status and prestige boosting activities [17], thus feeling inclined to patronize five-star hotels endorsed by reputable tour operators [18] [19]. In general, China has become one of the largest tourist generating countries in the world, substantially contributing to the rapid growth of the global tourism market [11].

Apart from the increasing global importance of Chinese travelers, travel mode preferences have also changed considerably over the last decade. Tourists from Asian countries, such as China, Japan as well as Korea have traditionally preferred to travel in groups, making group package tours (GPT) their most common mode of travel when visiting Taiwan [20] [21]. However, the international trend is now leaning towards more flexible travel and away from all-inclusive escorted tours [22]. As to Taiwan, changing travel mode patterns have been observable especially among Chinese tourists mostly as a result of by the Taiwanese government's decision to lessen restrictions on individual Chinese travelers. On June 28, 2011, the government implemented the Free Independent Travel (FIT) program (which was expanded in 2013), thereby increasing the previous limit on individual Chinese travelers from 1000 to 2000 visitors a day. The new policy has dramatically increased the number of FIT tourists. In 2014, over 1.2 million Chinese visited Taiwan under the program [1]. Altering travel mode preferences are likely to have significant impacts on tourism and related industries, assuming that individual and GPT travelers have different consumption patterns and travel motives.

This research analyses the changing travel mode preferences and shopping expenditures of Chinese and Japanese visitors to Taiwan. In the following sections, we look at the relevant literature, formulate research hypotheses and explain the applied research methodology. We conclude our study with a discussion on the most important findings of our empirical analysis. 


\section{Review of Literature}

Shopping and traveling are interconnected and the relationship between the two phenomena has undergone manifold complex changes. One of the most evident changes is that shopping increasingly emerges outside the consumers' local business communities [23]. Moreover, the notion of shopping has fundamentally shifted. Nowadays, shopping is increasingly viewed as a leisure activity rather than an economic necessity. The dramatic increase in the level of mobility, accelerated by globalization and growing wealth in established as well as in emerging economies, has contributed to this new dynamic [24] [25].

Wessely [26] identified two distinct modalities of shopping behavior in connection with tourism: tourism shopping and shopping tourism. In the first case, shopping only forms part of the overall activities, whereas in the latter it constitutes the explicit aim of traveling. In the past, shopping tourism was described as one of the manifestations of an informal private economy within developing countries [27]. That is travelers, crossed borders to neighboring countries with the objection of obtaining daily necessities or professional services that were either financially less attractive or not available in their home countries [26]. However, shopping as a leisure activity extended these conventional business practices of border economies to the domain of the rapidly increasing experience economy [28] [29], with shopping becoming the main objective of the overall travel experience. Apart from the growing segment of travelers wishing to obtain cheap products abroad there now is also an increasing number of people who desire to experience luxury. In spite of global economic recessions, the luxury market has already become an important segment in the travel and tourism industry [30]. Since tourists are reportedly more likely to purchase luxury products and spend higher amounts of money than local customers at shopping malls and places of public interest and entertainment, shopping tourism has been widely acknowledged as "a primary means of generating tourism revenue and contributing to economic development" [31].

There have been several studies investigating factors determining the consumption behavior of tourists. Lew and $\mathrm{Ng}$ [32] established that the level of tourism shopping expenditure is positively influenced by length of stay and number of visits. Wang [33] concluded that repeat visitors are comparatively more engaged in activities related to local culture and life and prefer more social activities, such as shopping, dining or visiting friends and relatives.

Keown [34] found that approximately $80 \%$ of Japanese visitors to Hawaii spent more than five hours on shopping. Approximately $30 \%$ of their spending was allocated to themselves and $60 \%$ to family, friends and work associates. One reason for this is that Japanese travelers are socially obliged to present small gifts to family and friends upon their return from international trips [35]. Other studies have segmented travelers by country. For example, Rosenbaum and Spears [12] studied the differences in travel spending patterns of tourists in Hawaii and found that Japanese tourists spent more on travel expenses, stay longer, and 
dedicate more time to shopping than tourists from other countries. Timothy [36] reported that Japanese tourists' most preferred purchases were food, clothing, handbags, tobacco, alcohol, cosmetics, shoes, scarves and handkerchiefs, chocolate and candy, leather products, and souvenir crafts.

Several other studies have revealed that tourists spend approximately one-third of their total travel expenditures on shopping [7] [37], and that shopping expenditures of tourists are positively influenced by socio-economic indicators, such as income, age as well as educational attainment [32] [38] [39] [40]. Moreover, female visitors were reported to spend more than their male counterparts [32].

Although individual travel has become increasingly popular among tourists, replacing conventional group package tours [22], there is a lack of research on the differences and communalities in spending patterns between the two travel modes. This study thus is the first attempt to investigate the relationship between travel mode and shopping expenditures of Chinese and Japanese tourists to Taiwan. In particular, we test the hypotheses that individual tourism has a much lower economic impact than GPT, and that age, gender, income, occupation as well as educational attainment is significant predictors of spending behavior.

Literature on empirical methodology indicates that the ordinary least square (OLS) model and the Tobit model estimates [41] [42] have traditionally been used to study travel consumer expenditures. In recent years, quantile regression (QR) has been adopted in tourism studies to analyze such expenditures. Marrocu, Paci, and Zara [43], for example, investigated tourist expenditure in Sardinia. Hung, Shang, and Wang [44] looked at the behavior of tourism consumption in Taiwan. Lew and $\mathrm{Ng}$ [32] analyzed the spending behavior of visitors to Hong Kong, and Chen and Chang [45] studied the influence of travel agents. The ordinary least square (OLS) estimation has traditionally been used to interpret the mean marginal effects of the explanatory variable on travel expenditures [46]; in contrast, QR assesses local behaviors at specific portions of the empirical distribution with reference to location measures rather than mean values [47].

This paper contributes to the literature by adding a QR analysis to highlight the heterogeneity in GPT and FIT travel modes in regard to tourist shopping expenditure. It also uses both linear and quantile regression to analyze the effects of socio-demographic and travel-related factors on the shopping expenditures of tourists from China and Japan with respect to GPT and FIT travel modes. Research results of this study may assist government agencies as well as tourism consultants in drafting policies and market development predictions regarding inbound tourism from China and Japan.

\section{Research Methodology}

\subsection{Data and Variables}

This study analyzed 7720 leisure travelers using data from the 2012 and 2013 
Annual Survey Report on Visitor Expenditures and Trends in Taiwan. Tourism Bureau of Taiwan In order to understand the tourism motivation, trends, consumption situations, perceptions and opinions of foreign tourists in Taiwan in the past few years, this survey was conducted to visit departing passengers at Taiwan's Taoyuan International Airport, Kaohsiung International Airport, and Songshan Airport respectively. Seventy percent (5688) of the respondents were from China and 28\% (2302) from Japan. Quota sampling was applied to achieve both random and sample representatives by controlling employment standards and the characteristics of inbound visitors.

Indicators used in this study were divided into three types: socio-demographic indicators, travel-related indicators, and shopping expenditures. Socio-demographic indicators included gender, age, place of residence, occupation, educational attainment, and income (see Table 1).

Travel-related indicators included visitor's travel mode choice, traveling with family members, length of stay, visitor's satisfaction scores, and previous travel experience. Travel mode choice was classified into group package tour (GPT) and free independent travel (FIT). FIT travelers were defined as those who only used a travel agency to book their accommodation and transportation. A 5-point Likert scale was employed to survey satisfaction with travel agencies and local tour operators. A distinction was also made between repeat visitors (those who had visited Taiwan during the previous three years) and first-time travelers. The last section of the questionnaire analyzed shopping expenditures consisting of clothing and accessories, jewelry, jade articles, local specialties, souvenirs, handicrafts, cigarettes, liquor, and medicine. The descriptive statistics are summarized in Table 1.

\subsection{Model Specification and Methodology}

At the household or family level, economic theory typically depicts consumption level as being determined by socioeconomic and travel-related factors [32] [43]. In this study, we adopted individual per-day shopping expenditures as the dependent variable and two distinct groups as independent variables: 1) socio-demographic factors such as gender, age, education, occupation, personal income, and residence; and 2) travel-related factors. The latter included traveling with family members, travel satisfaction, and repeat visitor experience. The following empirical model for tourist shopping expenditure was used:

$$
Y_{i j}=f\left(X_{i j}\right)
$$

where $i=1,2,3,4$ denotes the four main categories of tourists and $j=1, \cdots, N$ the ith individual. $Y$ is the per tourist per day shopping expenditure. $X$ is the two categories of explanatory variables consisting of both socio-demographic and travel-related factors. Table 1 contains the variable definitions and their explanations.

This paper applied least squares regression (LSR) as well as quantile regression. STATA 12 software package was used for the analysis. 
Table 1. Definition and explanation of variables in empirical models.

\begin{tabular}{|c|c|c|}
\hline Variable & Definition & Explanation \\
\hline \multicolumn{3}{|l|}{ Dependent variables } \\
\hline$Y$ & Shopping expenditures & $\begin{array}{l}\text { Shopping expenditures during their current trip } \\
\text { (US\$/per tourist per day). }\end{array}$ \\
\hline \multicolumn{3}{|l|}{ Independent variables } \\
\hline \multicolumn{3}{|l|}{ Travel-related factors } \\
\hline GPT & $\begin{array}{l}\text { Visitor's travel model choice is } \\
\text { group package tour }\end{array}$ & $\begin{array}{c}\text { Dummy, } 1 \text { if visitor's model choice is group package } \\
\text { tour and } 0 \text { otherwise }\end{array}$ \\
\hline Travel repeat & Travel repeat within three years & $\begin{array}{l}\text { Dummy, } 1 \text { if visitor has travel repeat to } \\
\text { Taiwan within three years and } 0 \text { otherwise }\end{array}$ \\
\hline $\begin{array}{l}\text { Traveling with family } \\
\text { members or friends }\end{array}$ & $\begin{array}{l}\text { Visitor's traveling has family } \\
\text { members or friends on the trip }\end{array}$ & $\begin{array}{l}\text { Dummy, } 1 \text { if visitor has family members or } \\
\text { friends on the trip and } 0 \text { otherwise }\end{array}$ \\
\hline Tourist's satisfaction & Visitor's satisfaction scores & $\begin{array}{l}\text { Visitor's satisfaction scores on travel agents and } \\
\text { tour guide services. Ranging } 1-5 \text { from strongly } \\
\text { negative to strongly positive evaluation }\end{array}$ \\
\hline \multicolumn{3}{|l|}{ Socio-demographic } \\
\hline Central & $\begin{array}{l}\text { Visitor's residence is in the } \\
\text { central area of China }\end{array}$ & $\begin{array}{l}\text { Dummy, } 1 \text { if visitor's residence is in the } \\
\text { north area of China and } 0 \text { otherwise }\end{array}$ \\
\hline South & $\begin{array}{l}\text { Visitor's residence is in the } \\
\text { southern area of China }\end{array}$ & $\begin{array}{l}\text { Dummy, } 1 \text { if visitor's residence is in the } \\
\text { southern area of China and } 0 \text { otherwise }\end{array}$ \\
\hline Hong Kong and Macao & $\begin{array}{l}\text { Visitor's residence is in the } \\
\text { Hong Kong or Macao }\end{array}$ & $\begin{array}{l}\text { Dummy, } 1 \text { if visitor's residence is in the } \\
\text { Hong Kong or Macao and } 0 \text { otherwise }\end{array}$ \\
\hline Male & Visitor is male & Dummy, 1 if visitor is male and 0 if visitor is female \\
\hline Age $30-39$ years & Visitor is age $30-39$ years & Dummy, 1 if visitor is age $30-39$ years and 0 otherwise \\
\hline Age 40 - 59 years & Visitor is age $40-59$ & Dummy, 1 if visitor is age $40-59$ and 0 otherwise \\
\hline Age Over 60 years & Visitor is over 60 years & Dummy, 1 if visitor is over 60 years and 0 otherwise \\
\hline Income $<$ US $\$ 29,999$ & $\begin{array}{l}\text { Visitor's personal annual income } \\
\text { level is lower than US } \$ 29,999 \text { per year }\end{array}$ & $\begin{array}{l}\text { Dummy, } 1 \text { if visitor's personal annual income level is } \\
\text { lower than US } \$ 29,999 \text { per year and } 0 \text { otherwise }\end{array}$ \\
\hline Income US\$30,000 - 69,999 & $\begin{array}{l}\text { Visitor's personal annual income level is } \\
\text { US } \$ 30,000-69,999 \text { per year }\end{array}$ & $\begin{array}{l}\text { Dummy, } 1 \text { if visitor's personal annual income level is } \\
\text { US } \$ 30,000-69,999 \text { per year and } 0 \text { otherwise }\end{array}$ \\
\hline Income US\$70,000 - 99,999 & $\begin{array}{l}\text { Visitor's personal annual income level is } \\
\text { US } \$ 70,000 \text { - 99,999 per year }\end{array}$ & $\begin{array}{l}\text { Dummy, } 1 \text { if visitor's personal annual income level is } \\
\text { US } \$ 70,000-99,999 \text { per year and } 0 \text { otherwise }\end{array}$ \\
\hline Secondary/High School & $\begin{array}{l}\text { The visitor's education level } \\
\text { is secondary/high school }\end{array}$ & $\begin{array}{l}\text { Dummy, } 1 \text { if visitor's education level is } \\
\text { high/vocational school and } 0 \text { otherwise }\end{array}$ \\
\hline College or above & $\begin{array}{l}\text { The visitor's education level } \\
\text { is college or above }\end{array}$ & $\begin{array}{l}\text { Dummy, } 1 \text { if visitor's education level is is } \\
\text { college or above and } 0 \text { otherwise }\end{array}$ \\
\hline Professional/Proprietor & $\begin{array}{l}\text { Visitor's occupation is } \\
\text { professional or proprietor }\end{array}$ & $\begin{array}{l}\text { Dummy, } 1 \text { if visitor's occupation is } \\
\text { professional or proprietor and } 0 \text { otherwise }\end{array}$ \\
\hline Junior White Collar & $\begin{array}{l}\text { Visitor's occupation is } \\
\text { junior white collar occupation }\end{array}$ & $\begin{array}{l}\text { Dummy, } 1 \text { if visitor's occupation is junior } \\
\text { white collar and } 0 \text { otherwise }\end{array}$ \\
\hline Blue Collar & Visitor's occupation is blue collar & $\begin{array}{l}\text { Dummy, } 1 \text { if visitor's occupation is } \\
\text { blue collar and } 0 \text { otherwise }\end{array}$ \\
\hline
\end{tabular}


Since QR can describe the behavior of each quantile in the conditional distribution of explained variables, its coefficients can show the degree of influence of explanatory variables on different explained variable quantiles. LSR can only provide the mean, whereas QR can provide the estimations of different quantiles. It thus allows for a clearer description of the complete distribution state of explained variables. At the same time, QR can also address the problem of data heteroscedasticity.

The QR method used by Lew and Ng [32] is shown below. Given $n$ observations of the dependent variable $y_{\mathrm{i}}$, and $k$ independent variables represented by the $k$ vector $x_{\mathrm{i}}$ or $i=1, \cdots, n$, the $k$ vector of $t$ th quantile regression coefficients, $\beta(\theta)$, minimizes:

$$
\min _{\beta(\theta)} \sum_{y_{i}-x_{i} \beta(\theta) \geq 0} \theta\left|y_{i}-x_{i} \beta(\theta)\right|+\sum_{i y_{i}-x_{i} \beta(\tau)<0}(1-\theta)\left|y_{i}-x_{i} \beta(\theta)\right|
$$

where $\theta$ is the quantile to be estimated, ranging between 0 and 1 . The $\theta$ value near zero implies more weight on negative residuals. At the other extreme-with highest $\theta$ values - it indicates more weight on positive residuals.

The estimator of the regression equation parameter is:

$$
\hat{\beta}(\theta)=\min _{\beta(\theta)} \sum_{y_{i} \geq x_{i} \beta(\theta)} \theta\left|y_{i}-x_{i} \beta(\theta)\right|+\sum_{y_{i}<x_{i} \beta(\theta)}(1-\theta)\left|y_{i}-x_{i} \beta(\theta)\right|
$$

This means that $\hat{\beta}(\theta)$ can be solved provided $\theta$ is given. Hence, any of the $k$ components of the quantile regression coefficients $\hat{\beta}(\theta)$ provide an estimate of the marginal effect of the associated independent variable $x_{j}$ on the dependent variable for the $t$ th quantile of the cohort holding the effects of the remaining independent variables fixed. Because QR coefficients are typically computed by a linear program, a simple method can be applied [32].

\section{Results}

The descriptive statistics of the samples are presented in Table 2. This study found that the majority of Chinese tourists $(57.9 \%)$ who traveled to Taiwan chose a group package tour, whereas the majority of Japanese tourists (63.1\%) preferred free independent travel. The largest cohort of Chinese visitors (27.0\%) was in the 20- to 29-year-old age category. Chinese FIT tourists were significantly older than GPT visitors, and Japanese tourists were slightly older than Chinese visitors. Those with college education and above comprised the largest percentage of travelers from both China (76.1) and Japan (82.1\%).

The majority of Chinese tourists were professionals/proprietors (FIT: 39.7; GPT: $38.7 \%$ ), whereas the majority of Japanese tourists had blue collar jobs (FIT: 47.2; GPT: $41.3 \%$ ). In terms of income, the largest group of Chinese tourists (26.4\%) belonged to the less than US $\$ 9999$ cohort, whereas the largest group of Japanese travelers (26.3\%) had an annual income of US $\$ 40,000$ - 69,999. In regard to residence, the largest percentage of Chinese travelers (39.4\%) came from Central China. 
Table 2. Profile of visitor characteristics.

\begin{tabular}{|c|c|c|c|c|c|c|c|c|}
\hline \multirow{3}{*}{ Variable } & \multicolumn{3}{|c|}{ China } & \multirow{3}{*}{$X^{2}$ test } & \multicolumn{3}{|c|}{ Japan } & \multirow{3}{*}{$X^{2}$ test } \\
\hline & $\begin{array}{c}\text { Foreign } \\
\text { Individual } \\
\text { Tour (\%) }\end{array}$ & $\begin{array}{c}\text { Group } \\
\text { Package } \\
\text { Tour (\%) }\end{array}$ & $\begin{array}{c}\text { All } \\
\text { visitors } \\
(\%)\end{array}$ & & $\begin{array}{c}\text { Foreign } \\
\text { Individual } \\
\text { Tour (\%) }\end{array}$ & $\begin{array}{c}\text { Group } \\
\text { Package } \\
\text { Tour (\%) }\end{array}$ & $\begin{array}{c}\text { All } \\
\text { visitors } \\
(\%)\end{array}$ & \\
\hline & $(\mathrm{n}=2397)$ & $(\mathrm{n}=3291)$ & $(\mathrm{n}=5688)$ & & $(\mathrm{n}=1283)$ & $(\mathrm{n}=749)$ & $(\mathrm{n}=2032)$ & \\
\hline \multicolumn{9}{|l|}{ Socio-demographic } \\
\hline \multicolumn{9}{|l|}{ Gender } \\
\hline Male & 40.1 & 37.2 & 38.4 & $4.5^{\star *}$ & 51.6 & 43.3 & 48.5 & $12.7^{\star *}$ \\
\hline Female & 59.9 & 62.7 & 61.6 & & 48.4 & 56.6 & 51.4 & \\
\hline \multicolumn{9}{|l|}{ Age } \\
\hline $12-19$ years & 4.84 & 3.2 & 3.94 & $538.9^{* *}$ & 1.3 & 1.2 & 1.2 & $94.7^{* *}$ \\
\hline $20-29$ years & 39.3 & 18.0 & 27.0 & & 23.7 & 17.4 & 21.4 & \\
\hline 30 - 39 years & 26.8 & 20.7 & 23.3 & & 26.7 & 16.0 & 22.7 & \\
\hline $40-49$ years & 14.3 & 25.7 & 20.9 & & 21.9 & 18.6 & 20.7 & \\
\hline 50 - 59 years & 9.5 & 17.8 & 14.3 & & 12.1 & 19.3 & 14.8 & \\
\hline Over 60 years & 5.0 & 14.3 & 10.4 & & 14.1 & 27.2 & 18.9 & \\
\hline \multicolumn{9}{|l|}{ Education } \\
\hline Primary Education or Below & 1.5 & 2.4 & 2.0 & $16.4^{* *}$ & 0.9 & 1.3 & 1.1 & 7.3 \\
\hline Secondary/High School & 19.8 & 23.3 & 21.8 & & 15.5 & 18.8 & 16.7 & \\
\hline College or above & 78.6 & 74.3 & 76.1 & & 83.4 & 79.8 & 82.1 & \\
\hline \multicolumn{9}{|l|}{ Occupation } \\
\hline Professional/Proprietor & 39.7 & 38.7 & 39.1 & $37.3^{* *}$ & 32.1 & 24.1 & 29.1 & $50.0^{* *}$ \\
\hline Junior White Collar & 2.4 & 3.4 & 3.0 & & 0.4 & 0.2 & 0.3 & \\
\hline Blue Collar & 36.3 & 30.6 & 33.0 & & 47.2 & 41.3 & 45.0 & \\
\hline $\begin{array}{c}\text { Others } \\
\text { (House keeper, Students, and Retired) }\end{array}$ & 21.4 & 27.2 & 24.8 & & 20.2 & 34.1 & 25.3 & \\
\hline \multicolumn{9}{|l|}{ Personal income } \\
\hline$<$ US\$9999 & 16.4 & 33.7 & 26.4 & $437.8^{* *}$ & 0.5 & 0.4 & 0.4 & $47.1^{* *}$ \\
\hline US $\$ 10,000-14,999$ & 18.0 & 20.5 & 19.5 & & 2.4 & 2.2 & 2.3 & \\
\hline US $\$ 15,000$ - 29,999 & 22.9 & 14.7 & 18.1 & & 6.3 & 10.5 & 7.9 & \\
\hline US $\$ 30,000$ - 39,999 & 10.1 & 4.1 & 6.6 & & 20.5 & 15.6 & 18.7 & \\
\hline US $\$ 40,000$ - 69,999 & 7.6 & 2.7 & 4.8 & & 27.4 & 24.4 & 26.3 & \\
\hline US\$70,000 - 99,999 & 2.4 & 0.7 & 1.4 & & 16.3 & 12.8 & 15.0 & \\
\hline Over US\$100,000 & 3.3 & 0.8 & 1.9 & & 7.0 & 4.67 & 6.1 & \\
\hline No fixed income & 19.1 & 22.5 & 21.1 & & 19.3 & 29.2 & 22.9 & \\
\hline \multicolumn{9}{|l|}{ Residence } \\
\hline Northern China & 11.6 & 15.8 & 14.0 & $1900^{* *}$ & & & & \\
\hline Central China & 22.0 & 52.1 & 39.4 & & & & & \\
\hline Southern China & 8.4 & 25.8 & 18.5 & & & & & \\
\hline
\end{tabular}




\section{Continued}

\begin{tabular}{|c|c|c|c|c|c|c|c|c|}
\hline Hong Kong and Macao & 57.8 & 6.2 & 27.9 & & & & & \\
\hline \multicolumn{9}{|l|}{ Travel-related } \\
\hline \multicolumn{9}{|l|}{$\begin{array}{l}\text { Traveling with family } \\
\text { members or friends }\end{array}$} \\
\hline Yes & 85.3 & 96.5 & 91.8 & $230.8^{* *}$ & 69.8 & 97.8 & 80.1 & $232.7^{* *}$ \\
\hline No & 14.6 & 3.4 & 8.1 & & 30.1 & 2.1 & 19.8 & \\
\hline Length of stay (days) & 6.6 & 6.4 & 6.5 & & 4.6 & 2.7 & 3.9 & \\
\hline Tourist's satisfaction & 4.3 & 4.4 & 4.4 & & 4.3 & 4.2 & 4.2 & \\
\hline \multicolumn{9}{|l|}{ Travel repeat } \\
\hline Yes & 43.2 & 3.7 & 20.4 & $1300^{* *}$ & 52.7 & 22.1 & 41.4 & $182.4^{\star *}$ \\
\hline No & 56.7 & 96.2 & 79.5 & & 47.2 & 77.8 & 58.5 & \\
\hline \multicolumn{9}{|l|}{ Travel shopping expenditures (US\$) } \\
\hline Clothing, accessories, and cosmetic & 39.7 & 44.6 & 42.5 & & 14.3 & 25.3 & 18.4 & \\
\hline $\begin{array}{l}\text { Jewelry, jade articles, } \\
\text { souvenirs, and handicrafts }\end{array}$ & 17.9 & 72.7 & 49.6 & & 3.4 & 14.0 & 7.3 & \\
\hline Local specialties and tea & 35.0 & 52.9 & 45.3 & & 38.2 & 73.6 & 51.2 & \\
\hline Cigarettes and liquor & 1.8 & 7.3 & 5.0 & & 0.6 & 2.6 & 1.3 & \\
\hline $\begin{array}{c}3 \mathrm{C} \text { (Computer, consume } \\
\text { electronics, and communication) }\end{array}$ & 2.6 & 5.8 & 4.4 & & 0.3 & 0.1 & 0.2 & \\
\hline Other & 3.8 & 4.0 & 3.9 & & 2.0 & 0.8 & 1.5 & \\
\hline Total shopping expenditures & 101.0 & 188.6 & 151.7 & & 58.9 & 116.6 & 80.2 & \\
\hline
\end{tabular}

NOTES: ${ }^{*}$ Denotes $5 \%$ levels of significance respectively.

The average shopping expenditure per tourist per day was US $\$ 151.70$ for Chinese tourists and US $\$ 80.20$ for Japanese tourists. Chinese GPT travelers had the highest average expenditure per tourist per day (US\$188.60); the highest average expenditure for Japanese tourists (US\$116.60) was also made by GPT travelers. Japanese FIT travelers had the lowest average expenditure (US\$58.90) per person per day.

The average Chinese tourist in our sample spent US $\$ 42.50$ per day on clothing and accessories; US $\$ 49.60$ on jewelry, jade articles, souvenirs, and handicrafts; and US $\$ 45.30$ on local specialties and tea. Considerably less money was spent per day on cigarettes, liquor, and medicine (US\$5.00) and on computer, consumer electronics, and communications (US\$4.40). Chinese GPT visitors spent an average of US\$72.70 on jewelry, jade articles, souvenirs, and handicrafts. Chinese FIT tourists preferred to buy clothing, accessories, and cosmetics. Table 2 reveals a rather different consumption behavior among Japanese tourists, who spent most of their money on tea and other local specialties.

In Table 3 and Table 4, we report the results obtained by applying linear regression and quantile regression with nine conditional quantiles $(\theta=0.1,0.2$, $0.3,0.4,0.5,0.6,0.7,0.8$, and 0.9 ) with shopping expenditure as the dependent 
Table 3. Estimated coefficients for LSR and QR on shopping expenditure. Dependent variable: mainland Chinese shopping expenditure per tourist per day.

\begin{tabular}{|c|c|c|c|c|c|}
\hline \multirow{2}{*}{ Variables } & \multirow{2}{*}{ LSR } & \multicolumn{4}{|c|}{ QR } \\
\hline & & 0.1 & 0.2 & 0.3 & 0.4 \\
\hline GPT & $29.016^{* *}$ & $15.414^{\star *}$ & $22.549^{* *}$ & $27.773^{\star *}$ & $33.548^{\star *}$ \\
\hline Travel repeat & 27.068 & -1.572 & 0.479 & 1.248 & 3.146 \\
\hline Traveling with family members or friends & $51.914^{* *}$ & $4.868^{\star *}$ & $6.996^{* *}$ & $9.312^{* *}$ & $9.192^{* *}$ \\
\hline Satisfaction & -17.205 & 0.743 & 0.552 & 0.359 & 0.691 \\
\hline Central area of China & 7.926 & $4.835^{* *}$ & $8.057^{* *}$ & $13.296^{* *}$ & $20.178^{\star *}$ \\
\hline South area of China & $34.903^{* *}$ & $5.068^{\star *}$ & $7.643^{* *}$ & $17.384^{\star *}$ & $24.712^{\star *}$ \\
\hline Hong Kong and Macao & $-117.262^{\star \star}$ & -0.922 & -1.752 & -1.619 & -2.515 \\
\hline Male & -0.888 & $-2.806^{\star *}$ & $-4.010^{* *}$ & $-5.588^{* *}$ & $-5.576^{* *}$ \\
\hline Age 30 - 39 years & -0.496 & 0.860 & 1.865 & 2.327 & 1.366 \\
\hline Age 40 - 59 years & $51.816^{* *}$ & $3.667^{\star *}$ & $7.351^{* *}$ & $9.600^{* *}$ & $15.260^{\star *}$ \\
\hline Age Over 60 years & 7.770 & -0.108 & -0.414 & 1.865 & 2.500 \\
\hline$<\mathrm{US} \$ 29,999$ & -6.946 & 0.6422 & -0.172 & 1.418 & 1.632 \\
\hline US $\$ 30,000-69,999$ & $77.776^{\star *}$ & 2.642 & 1.949 & 6.301 & 4.654 \\
\hline US\$70,000 - 99,999 & $161.238^{\star \star}$ & 4.017 & 6.492 & 9.728 & 14.228 \\
\hline Secondary/High School & -26.656 & 1.572 & 0.940 & 2.697 & 2.831 \\
\hline College or above & 45.060 & $25.024^{* *}$ & $17.578^{* *}$ & $18.234^{* *}$ & 11.852 \\
\hline Professional/Proprietor & 25.973 & $6.691^{* *}$ & $7.801^{* *}$ & $9.116^{* *}$ & $15.046^{\star *}$ \\
\hline Junior White Collar & -4.875 & $7.454^{* *}$ & $8.628^{* *}$ & 7.384 & 7.716 \\
\hline Blue Collar & 9.824 & $5.820^{\star *}$ & $8.075^{\star *}$ & $8.751^{\star *}$ & $12.876^{\star *}$ \\
\hline Intercept & $165.862^{\star *}$ & -4.015 & 0.018 & 0.511 & 2.283 \\
\hline \multirow{2}{*}{ Variables } & \multicolumn{5}{|c|}{ QR } \\
\hline & 0.5 & 0.6 & 0.7 & 0.8 & 0.9 \\
\hline GPT & $38.530^{* *}$ & $43.207^{\star *}$ & $54.700^{\star *}$ & $62.977^{\star \star}$ & $63.468^{\star *}$ \\
\hline Travel repeat & $5.0255^{* *}$ & 4.838 & 2.744 & 12.101 & 7.855 \\
\hline Traveling with family members or friends & $12.158^{* *}$ & $14.227^{\star *}$ & $14.050^{* *}$ & $16.957^{\star *}$ & 25.172 \\
\hline Satisfaction & -0.100 & -1.552 & -3.631 & $-12.248^{\star *}$ & -7.971 \\
\hline Central area of China & $27.135^{\star *}$ & $34.297^{\star *}$ & $51.223^{* *}$ & $56.783^{* *}$ & $65.035^{* *}$ \\
\hline South area of China & $30.244^{\star *}$ & $36.424^{\star *}$ & $51.081^{\star *}$ & $57.989^{\star *}$ & $92.319^{* *}$ \\
\hline Hong Kong and Macao & -5.942 & $-12.860^{\star *}$ & $-16.130^{* *}$ & $-43.696^{\star *}$ & $-101.355^{\star *}$ \\
\hline Male & $-6.9959^{\star \star}$ & $-5.521^{\star *}$ & $-8.628^{* *}$ & -9.696 & -13.671 \\
\hline Age 30 - 39 years & 3.163 & 1.552 & 5.131 & 11.004 & 12.915 \\
\hline Age 40 - 59 years & $17.018^{\star *}$ & $22.834^{* *}$ & $33.743^{* *}$ & $48.468^{* *}$ & $76.157^{\star *}$ \\
\hline Age Over 60 years & 3.621 & -1.208 & 4.027 & 4.9341 & -0.778 \\
\hline$<\mathrm{US} \$ 29,999$ & 0.632 & -0.060 & -4.103 & -8.158 & -16.134 \\
\hline US $\$ 30,000-69,999$ & 6.784 & 8.474 & 13.484 & $32.185^{\star *}$ & $64.578^{\star *}$ \\
\hline US\$70,000 - 99,999 & 27.250 & $52.683^{* *}$ & $66.263^{\star *}$ & $166.494^{* *}$ & $277.302^{\star \star}$ \\
\hline Secondary/High School & 2.874 & -2.669 & -19.879 & -1.645 & -112.466 \\
\hline College or above & 5.196 & -0.7389 & -14.386 & -12.195 & -25.303 \\
\hline Professional/Proprietor & $17.136^{* *}$ & $25.806^{* \star}$ & $34.191^{\star \star}$ & $27.601^{\star \star}$ & $69.988^{\star *}$ \\
\hline Junior White Collar & 6.196 & 5.842 & 21.814 & 14.712 & 37.952 \\
\hline Blue Collar & $15.633^{* *}$ & $19.689^{* *}$ & $28.624^{\star *}$ & $21.175^{\star *}$ & $42.704^{\star *}$ \\
\hline Intercept & 11.568 & 33.065 & $71.269^{* *}$ & $133.683^{\star *}$ & $304.335^{\star \star}$ \\
\hline Pseudo R2 & 0.0624 & 0.0658 & 0.0727 & 0.0793 & 0.0890 \\
\hline
\end{tabular}

Number of observations 5688. Unless otherwise indicated, all explanatory variables are expressed as dummy variables. Estimation method: Quantile Regressions. Significance based on bootstrapped standard errors (1000 replications): ${ }^{*} 5 \%$. 
Table 4. Estimated coefficients for LSR and QR on shopping expenditure. Dependent variable: Japanese shopping expenditure per tourist per day.

\begin{tabular}{|c|c|c|c|c|c|}
\hline \multirow{2}{*}{ Variables } & \multirow{2}{*}{ LSR } & \multicolumn{4}{|c|}{ QR } \\
\hline & & 0.1 & 0.2 & 0.3 & 0.4 \\
\hline GPT & $54.606^{\star *}$ & $9.840^{* *}$ & $14.823^{* *}$ & $21.268^{* *}$ & $25.577^{\star *}$ \\
\hline Travel repeat & -1.055 & -1.158 & -2.362 & -1.554 & -2.246 \\
\hline Traveling with family members or friends & 12.619 & $3.204^{\star *}$ & $4.303^{* *}$ & $6.519^{* *}$ & $7.562^{* *}$ \\
\hline Satisfaction & -0.219 & 0.921 & 0.696 & 0.536 & $-8.99 \mathrm{e}-09$ \\
\hline Male & $-26.192^{\star *}$ & $-2.934^{\star *}$ & $-4.731^{\star *}$ & $-7.071^{\star \star}$ & $-10.362^{\star *}$ \\
\hline Age 30 - 39 years & -17.086 & 0.4974 & -0.270 & -2.157 & -2.676 \\
\hline Age 40 - 59 years & -2.174 & $3.431^{\star *}$ & $3.992^{* *}$ & 4.169 & 2.742 \\
\hline Age Over 60 years & -0.2531 & $3.725^{\star *}$ & 2.616 & 2.702 & 4.410 \\
\hline$<\mathrm{US} \$ 29,999$ & 28.879 & 0.272 & 2.041 & -0.0738 & -1.916 \\
\hline US $\$ 30,000-69,999$ & 5.304 & 4.019 & $6.786^{* *}$ & 5.287 & 5.740 \\
\hline US\$70,000 - 99,999 & 28.791 & 3.8978 & $7.681^{* *}$ & 6.996 & 5.983 \\
\hline Secondary/High School & -27.082 & 16.416 & -5.742 & -25.636 & -13.005 \\
\hline College or above & 82.186 & -7.091 & 3.927 & 20.413 & 19.273 \\
\hline Professional/Proprietor & 32.483 & -0.163 & -0.737 & 3.074 & 8.978 \\
\hline Junior White Collar & 19.964 & -0.3070 & -2.674 & -3.837 & 0.269 \\
\hline Blue Collar & 5.320 & 0.0285 & -1.848 & 1.127 & 4.572 \\
\hline Intercept & 65.174 & -17.965 & 9.515 & 34.225 & 28.400 \\
\hline \multirow{2}{*}{ Variables } & \multicolumn{5}{|c|}{ QR } \\
\hline & 0.5 & 0.6 & 0.7 & 0.8 & 0.9 \\
\hline GPT & $34.567^{\star \star}$ & $41.862^{\star *}$ & $57.437^{\star *}$ & $70.191^{\star *}$ & $82.954^{* *}$ \\
\hline Travel repeat & -1.986 & -1.989 & -3.391 & -1.364 & -3.488 \\
\hline Traveling with family members or friends & $8.1961^{\star \star}$ & $8.827^{* *}$ & 8.329 & 10.278 & $23.690^{* *}$ \\
\hline Satisfaction & 0.360 & 1.010 & $1.50 \mathrm{e}-08$ & -0.964 & -3.229 \\
\hline Male & $-12.879^{\star *}$ & $-15.110^{\star *}$ & $-17.573^{\star *}$ & $-29.938^{\star *}$ & $-33.767^{\star \star}$ \\
\hline Age 30 - 39 years & $-5.688^{\star *}$ & -3.600 & -2.509 & -1.364 & -5.177 \\
\hline Age 40 - 59 years & 2.210 & 7.732 & $14.652^{\star *}$ & 11.309 & -7.215 \\
\hline Age Over 60 years & 5.273 & 4.756 & 7.324 & 18.440 & 17.701 \\
\hline$<$ US $\$ 29,999$ & -3.415 & 0.3944 & 11.365 & 25.851 & 40.835 \\
\hline US $\$ 30,000-69,999$ & 2.633 & 6.339 & 19.232 & 28.424 & 39.858 \\
\hline US\$70,000 - 99,999 & 4.906 & 8.852 & 24.355 & $42.729^{* *}$ & $104.405^{* *}$ \\
\hline Secondary/High School & -24.337 & -14.793 & 25.906 & 62.539 & -380.565 \\
\hline College or above & 19.779 & 100.830 & 113.023 & 168.95 & 152.991 \\
\hline Professional/Proprietor & $17.921^{\star \star}$ & 17.953 & 7.028 & 11.787 & 34.412 \\
\hline Junior White Collar & 3.463 & -3.590 & -18.960 & -37.650 & 17.928 \\
\hline Blue Collar & 10.245 & 9.234 & -5.779 & -12.862 & -15.380 \\
\hline Intercept & 43.162 & 36.704 & 13.060 & -1.025 & 474.952 \\
\hline Pseudo R2 & 0.0581 & 0.0597 & 0.0700 & 0.0780 & 0.0817 \\
\hline
\end{tabular}

Number of observations 2032. Unless otherwise indicated, all explanatory variables are expressed as dummy variables. Estimation method: Quantile Regressions. Significance based on bootstrapped standard errors (1000 replications): ${ }^{*} 5 \%$. 
variable. Table 3 shows that when using LSR to estimate shopping expenditures, the estimated coefficients for Chinese tourists who travel via group package tours, travel with family members, reside in southern China, are aged 40-59 years old, and have income levels of US\$30,000 - 69,999 or US\$70,000 - 99,999 is positive and reaches the $5 \%$ level of significance. The estimated coefficient of the US\$70,000 - 99,999 income level is the highest (161.23) among the model's independent variables, which means that the average shopping expenditure of Chinese tourists belonging to this income group is US $\$ 161.23$ higher than those of other income level groups.

The estimated coefficient for Japanese tourists who travel via group package tour is positive and the highest (54.6) among the model's independent variables. This means that the average shopping expenditure of Japanese GPT tourists is US $\$ 54.60$ higher than that of Japanese FIT tourists (see Table 4).

In using QR for estimation, when the conditional quantile is at $\theta=0.1-0.9$, the estimated coefficient for Chinese tourists who travel by GPT is positive and reaches the 5\% level of significance. This implies that the average shopping expenditures of the 0.1 to 0.9 quantile of GPT tourists was US $\$ 15.414$ to $\$ 63.468$ higher than for free independent travelers (Table 3 and Figure 1, first row, first panel).Total shopping expenditure of the upper $10 \%$ is 2.18 times the total shopping expenditure of the LSR-estimated average shopping expenditure of US\$29.016.

In using QR for estimation, when the conditional quantile is at $\theta=0.9$, the estimated coefficient of the US\$70,000 - 99,999 income level is positive and the highest (277.302). This means that the average shopping expenditure of the upper $10 \%$ of tourists in the US $\$ 70,000$ - 99,999 income level was US $\$ 277.302$ higher than that of tourists at other income levels (Table 3 and Figure 1, third row, first panel). The average shopping expenditure among the 0.1 to 0.9 quantile of professional/proprietor tourists was US $\$ 6.691$ to US\$69.988 higher than that of tourists with other occupations (see Table 3 and Figure 1, third row, third panel). This occupational dependency is in line with previous research findings [32] [48].

Travelers aged 40 to 59 spent significantly more than travelers of any other age group over the entire spectrum of quantiles, with incremental spending being higher for the higher quantiles. In this respect, our findings differ from those of Wang et al. [48] as well as from Lew and $\mathrm{Ng}$ [32], which found that Chinese tourists aged 26 to 40 had higher shopping expenditures than other age groups when visiting Hong Kong. This discrepancy could be due to the fact that Chinese prefer to use GPT to travel to Taiwan and FIT to travel to Hong Kong. Furthermore, GPT customers tend to be older than FIT travelers and prefer to buy more expensive items, such as jewelry, jade articles, and local specialties.

In using QR for estimation, when the conditional quantile is at $\theta=0.7-0.9$ (reflecting the upper $30 \%$ of shopping spending), the estimated value for Japanese GPT tourists is positive (see Table 4 and Figure 2, first row, first panel) 

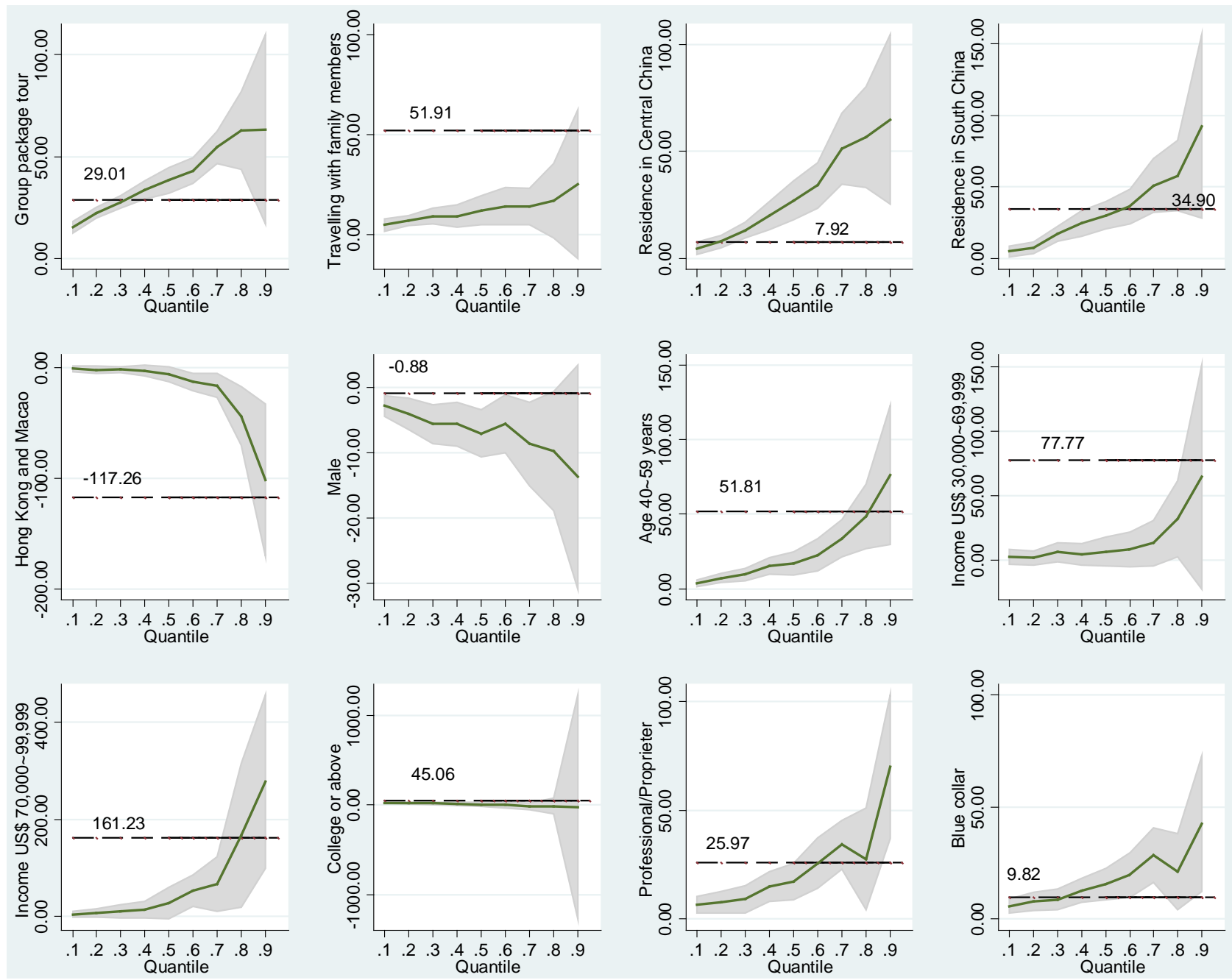

Figure 1. The influences of travel mode, socio-demographics, and travel characteristic factors on mainland Chinese tourist shopping expenditure.

and significantly greater than that for the LSR estimate. This implies that the average shopping expenditures for the upper $30 \%$ of tourists who travel by group package tour is US $\$ 57.437$ to 82.954 higher than that for FIT tourists, which is greater than the LSR-estimated average shopping expenditure of US\$54.606.

Japanese tourists traveling with family members or friends consumed significantly more than individual visitors. (Results were insignificant only at $\theta=0.7$ 0.8.) When the conditional quantile is at $\theta=0.8-0.9$, the estimated value for male Japanese tourists is negative (see Table 4 and Figure 2, first row, third panel) and significantly greater than that for the LSR estimate. This implies that the average shopping expenditure of the upper $20 \%$ of male tourists was US $\$ 29.938$ to 33.767 less than that for female tourists. This gender difference is in line with previous research suggesting that women are more likely to choose a destination in order to shop or visit friends and relatives [49]. These findings also confirm previous evidence on the relevance of income as one of the most important drivers of Japanese tourist shopping expenditure [14]. In addition, the 

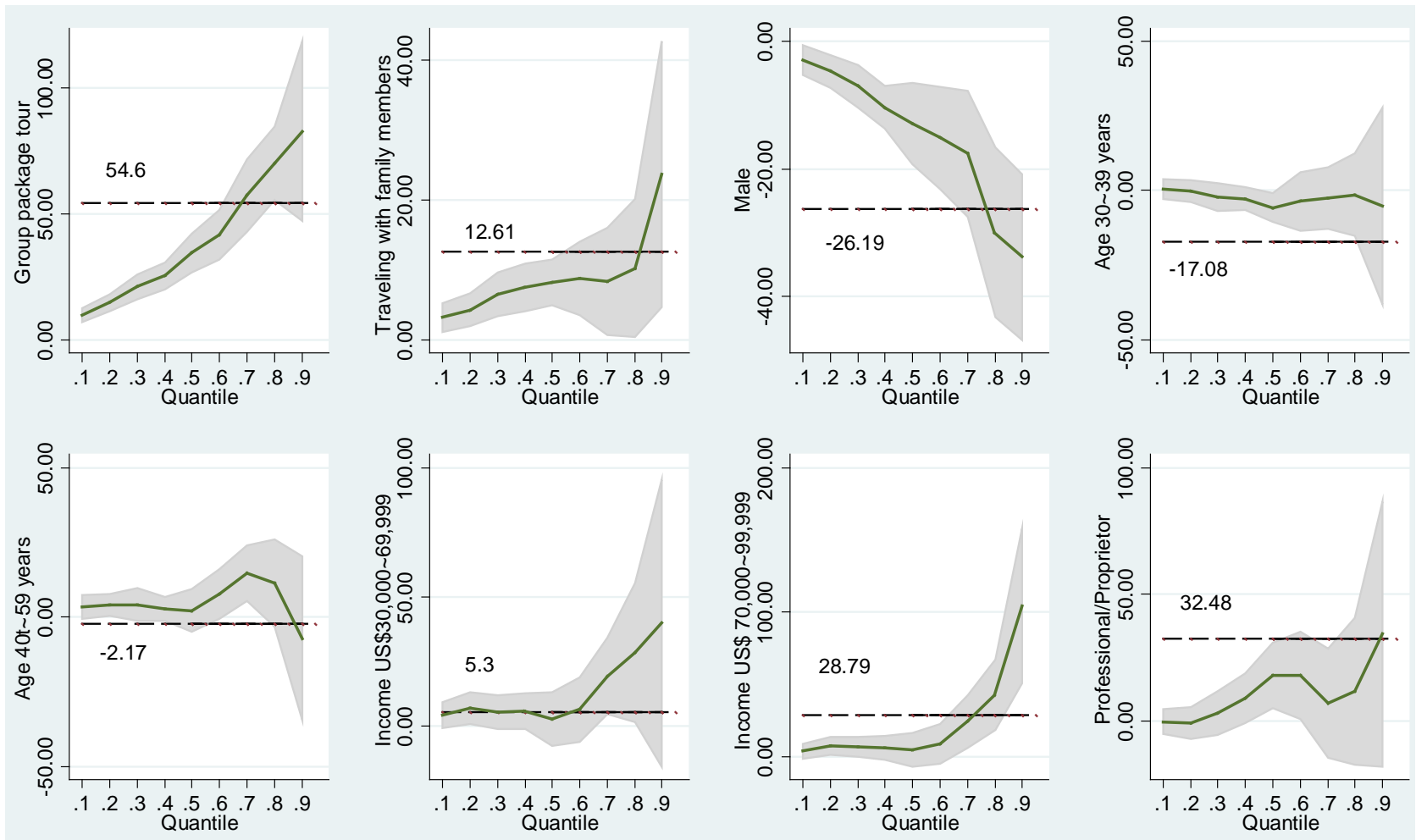

Figure 2. The influences of travel mode, socio-demographics, and travel characteristic factors on Japanese tourist shopping expenditure.

findings show that the daily shopping expenditure of the upper ten percent of Chinese tourists averaged US $\$ 277.30$, whereas the daily shopping expenditure of Japanese visitors on consumer goods was US $\$ 104.40$. Thus, Chinese tourists offer the Taiwanese tourism industry considerably more business opportunities than their Japanese counterparts.

\section{Conclusions}

This study found that the majority of Chinese tourists (57.9\%) choose GPT as their preferred travel mode, whereas Japanese tourists (63.1\%) strongly favor FIT. The Japanese preference contradicts findings of previous studies, such as those by Kim and Lee [50], which suggest that Japanese prefer group travel. QR estimated coefficients for the entire spectrum of quantiles show that both Japanese and Chinese GPT travelers have higher expenditures than FIT visitors. Higher spending behavior is also more common among visitors with professional/proprietor backgrounds and those traveling with family or friends.

Although the latter reflects previous findings by Lew and $\mathrm{Ng}$ [32], this study provides evidence that income is a crucial determinant of spending behavior among Chinese tourists. GPT visitors of the highest income cohort (US\$70,000 99,999) spent considerably more money during their trip to Taiwan than other mainland Chinese tourists. Moreover, Chinese travelers aged 40 to 59 years spent significantly more than tourists of other age groups. The latter finding differs from those of Wang et al. [48] and Lew and $\mathrm{Ng}$ [32], which showed that 
Chinese tourists aged 26 to 40 had higher shopping expenditures than other age groups when visiting Hong Kong. As explained above, however, this discrepancy could be due to the fact that Chinese tourists prefer GPT when traveling to Taiwan and FIT when traveling to Hong Kong. Furthermore, GPT customers tend to be older than FIT travelers and buy more expensive items, such as jewelry, jade articles, and local specialties.

For cultural reasons, Japanese visitors (both GPT and FIT) spent over $60 \%$ of their total expenditures on buying tea or other local specialties as gifts for family members and friends. Quantile regression estimates suggest that Japanese GPT tourists with a university degree who are over 40 had higher expenditures than other visitors.

These findings have some important marketing implications for the tourism industry. Tour operators, for example, could take advantage of Japanese gift buying behavior and provide more time and opportunities for Japanese GPT visitors to purchase such products. In addition, marketing messages should target middle-aged members of social clubs, alumni associations and business cooperatives to encourage group travel. Additional segments to target include Japanese FIT visitors with income levels above US $\$ 70,000$, female travelers, and those traveling with friends or family members. For example, potential female FIT tourists could be provided with special information regarding wellness, clothing and other products and services.

In recent years, the number of Chinese FIT visitors has increased dramatically and become an important segment of the tourism market. Most mainland Chinese FIT tourists are aged 20 to 39 years and tend to purchase clothing, accessories, cosmetics and local specialties. According to our quantile regression analysis, mainland Chinese FIT visitors at the 0.9 quantile of the upper income cohort (US\$70,000 - 99,999) had the highest spending levels. Expenditures of professional/proprietor FIT tourists increased at higher quantiles. Consequently, destination managers could target this segment and create marketing materials focused on high quality, higher priced products, and services. This is could be an effective strategy because luxury items sold in Taiwan are more likely to be authentic and significantly cheaper than in mainland China.

Another important variable in helping to segment the tourism market is educational attainment. Mainland Chinese travelers with a university degree exhibit higher spending at the 0.1 to 0.3 quantiles than other travelers. This group of visitors mostly consists of young people with lower disposable income who choose FIT as their preferred travel mode, obtain travel information online, stay at budget hotels in the Taipei area, and like to go shopping in the popular Hsinmending area of the city.

This study has confirmed the usefulness of quantile regression techniques in discovering different marginal effects that are not immediately obvious. As pointed out in the literature, QR's ability to highlight the significance of each independent variable on the dependent variable across the full spectrum of the distribution is especially helpful in exploring the spending behavior of tourists 
[43]. This salient feature allows policy makers to better allocate marketing resources. However, as Lew and $\mathrm{Ng}$ [32] emphasize, the quantile regression technique has its limitations. For example, further segmentation of heavy spenders based on their socio-economic characteristics would require the application of other methods of analysis, such as the CHAID approach [51].

This study focused solely on the spending behavior of Japanese and Chinese tourists; additional studies could also be conducted on the spending behavior of tourists from other countries visiting Taiwan. Furthermore, this study did not investigate other influential factors, such as buying motives or environmental circumstances, which could also be the focus of future research.

\section{Acknowledgements}

This study was carried out thanks to supporting free data received from The Center for Survey Research (CSR), Academia Sinica (Taiwan).

\section{References}

[1] Tourism Bureau (2015) Tourism Statistics for 2014. http://admin.taiwan.net.tw/upload/statistic/20150123/181e6bf8-361c-4118-881e-dee ecf273f7d.xls

[2] Tourism Bureau (2014) 2013 Annual Survey Report on Visitors Expenditure and Trends in Taiwan.

http://admin.taiwan.net.tw/upload/statistic/20140730/8ff4114e-86dd-4ec6-a6c3-c0c 13262 ca7b.doc

[3] Tourism Bureau (2013) 2012 Annual Survey Report on Visitors Expenditure and Trends in Taiwan.

http://admin.taiwan.net.tw/upload/statistic/20130718/ef850682-1714-4f42-9ba7-22d d963ea57c.doc

[4] EU SME Centre (2014) Tourism Market in China. EU SME Centre, Beijing.

[5] Kim, S. and Littrell, M. (1999) Predicting Souvenir Purchase Intentions. Journal of Travel Research, 38, 153-62. https://doi.org/10.1177/004728759903800208

[6] Ko, T. (1999) The Issues and Implications of Escorted Shopping Tours in a Tourist Destination Region: The Case Study of Korean Package Tourists in Australia. Journal of Travel and Tourism Marketing, 8, 71-80.

https://doi.org/10.1300/J073v08n03_04

[7] Turner, L. and Reisinger, Y. (2001) Shopping Satisfaction for Domestic Tourists. Journal of Retailing and Consumer Services, 8, 15-27.

https://doi.org/10.1016/S0969-6989(00)00005-9

[8] Wang, D. (2004) Hong Kongers' Cross-Border Consumption and Shopping in Shenzhen: Patterns and Motivations. Journal of Retailing and Consumer Services, 11, 149-159. https://doi.org/10.1016/S0969-6989(03)00014-6

[9] Kinley, T., Josiam, B. and Kim, Y. (2002) Why and Where Tourists Shop: Motivations of Tourist-Shoppers and Their Preferred Shopping Center Attributes. Journal of Shopping Center Research, 10, 7-28.

[10] Bojanic, D.C. (2011) The Impact of Age and Family Life Experiences on Mexican Visitor Shopping Expenditures. Tourism Management, 32, 406-414.

https://doi.org/10.1016/j.tourman.2010.03.012 
[11] Correia, A. and Kozak, M. (2016) Tourists' Shopping Experiences at Street Markets: Cross-Country Research. Tourism Management, 56, 85-95. https://doi.org/10.1016/j.tourman.2016.03.026

[12] Rosenbaum, M. and Spears, D. (2006) An Exploration of Spending Behaviors among Japanese Tourists. Journal of Travel Research, 44, 467-473. https://doi.org/10.1177/0047287505282949

[13] Rosenbaum, M. and Spears, D. (2005) Who Buys That? Who Does What? Analysis of Cross-Cultural Consumption Behaviours among Tourists in Hawaii. Journal of Vacation Marketing, 11, 235-247. https://doi.org/10.1177/1356766705055710

[14] Jang, S., Bai, B., Hong, G-S. and O’Leary, J. (2004) Understanding Travel Expenditure Patterns: A Study of Japanese Pleasure Travelers to the United States by Income Level. Tourism Management, 25, 331-41. https://doi.org/10.1016/S0261-5177(03)00141-9

[15] United Nations World Tourism Organization (2003) Chinese Outbound Tourism. UNWTO, Madrid.

[16] Li, X., Lai, C., Harrill, R., Kline, S. and Wang, L. (2011) When East Meets West: An Exploratory on Chinese Outbound Tourists' Travel Expectations. Tourism Management, 32, 741-749. https://doi.org/10.1016/j.tourman.2010.06.009

[17] Mok, C. and DeFranco, A. (1999) Chinese Cultural Values: Their Implications for Travel and Tourism Marketing. Journal of Travel and Tourism Marketing, 8, 99-114. https://doi.org/10.1300/J073v08n02_07

[18] Nerine, B. (2011) Decision Factors for Domestic Package Tours-Case Study of a Region in South Africa. TURIZAM, 15, 53-64. https://doi.org/10.5937/Turizam1102053B

[19] Wong, C.-K. and Kwong, W.-Y. (2004) Outbound Tourists' Selection Criteria for Choosing All-Inclusive Package Tours. Tourism Management, 25, 581-592. https://doi.org/10.1016/j.tourman.2003.06.002

[20] Wang, Y. and Sheldon, P. (1995) The Sleeping Dragon Awakes: The Outbound Chinese Travel Market. Journal of Travel and Tourism Marketing, 4, 41-54. https://doi.org/10.1300/J073v04n04_03

[21] Qu, H. and Li, I. (1997) The Characteristics and Satisfaction of Mainland Chinese Visitors to Hong Kong. Journal of Travel Research, 35, 37-41. https://doi.org/10.1177/004728759703500406

[22] Mak, J. (2004) Tourism and the Economy. University of Hawaii Press, Honolulu.

[23] Tömöri, M. (2010) Investigating Shopping Tourism along the Borders of Hungary: A Theoretical Perspective. GeoJournal of Tourism and Geosites, 6, 202-210.

[24] Dridea, C. and Sztruten, G. (2009) The Impact of Shopping Tourism on the Future of Leisure Services. Analele UniversităTii Din Oradea WtiinTe Economice, 2, 67-72.

[25] Friedrich, W. and Sattler, K. (2005) Shopping Tourism in Germany-Impulses in the Development of Tourism and Retail Commerce in Germany. Köln: ISG-Institut für Sozialforschung und Gesellschaftspolitik.

[26] Wessely, A. (2002) Travelling People, Travelling Objects. Cultural Studies, 16, 3-15. https://doi.org/10.1080/09502380110075234

[27] Saayman, M. and Saayman, A. (2012) Shopping Tourism or Tourists Shopping? A Case Study of South Africa's African Tourism Market. Tourism Economics, 18, 1313-1329. https://doi.org/10.5367/te.2012.0169

[28] Oh, H., Fiore, A. and Jeoung, M. (2007) Measuring Experience Economy Concepts: Tourism Applications. Journal of Travel Research, 46, 119-132. https://doi.org/10.1177/0047287507304039 
[29] Sternberg, E. (1997) The Iconography of the Tourism Experience. Annals of Tourism Research, 24, 951-969. https://doi.org/10.1016/S0160-7383(97)00053-4

[30] Park, K., Reisinger, Y. and Noh, E. (2010) Luxury Shopping in Tourism. International Journal of Tourism Research, 12, 164-178.

[31] Paige, R. and Littrell, M. (2003) Tourism Activities and Shopping Preferences. Journal of Shopping Center Research, 10, 7-25.

[32] Lew, A. and Ng, P. (2012) Using Quantile Regression to Understand Visitor Spending. Journal of Travel Research, 51, 278-288. https://doi.org/10.1177/0047287511410319

[33] Wang, D. (2004) Tourist Behaviour and Repeat Visitation to Hong Kong. Tourism Geographies, 6, 99-118. https://doi.org/10.1080/14616680320001722355

[34] Keown, C. (1989) A Model of Tourists' Propensity to Buy: The Case of Japanese Visitors to Hawaii. Journal of Travel Research, 27, 31-34. https://doi.org/10.1177/004728758902700306

[35] Mok, C. and Lam, T. (2000) Travel-Related Behavior of Japanese Leisure Tourists: A Review and Discussion. Journal of Travel and Tourism Marketing, 9, 171-184. https://doi.org/10.1300/J073v09n01_10

[36] Timothy, D. (2005) Shopping Tourism, Retailing and Leisure. Channel View, Clevedon.

[37] LeHew, M. and Wesley, S. (2007) Tourist Shoppers' Satisfaction with Regional Shopping Mall Experiences. International Journal of Culture, Tourism and Hospitality Research, 1, 82-96. https://doi.org/10.1108/17506180710729628

[38] Gholipour, H., Tajaddini, R. and Al-mulali, U. (2014) Does Personal Freedom Influence Outbound Tourism? Tourism Management, 41, 19-25. https://doi.org/10.1016/j.tourman.2013.08.010

[39] He, L., Li, X., Harrill, R. and Cardon, P. (2014) Examining Japanese Tourists' US-Bound Travel Constraints. Current Issues in Tourism, 17, 705-722. https://doi.org/10.1080/13683500.2012.749842

[40] Oh, J., Cheng, C., Lehto, X. and O’Leary, J. (2004) Predictors of Tourists' Shopping Behaviour: Examination of Socio-Demographic Characteristics and Trip Typologies. Journal of Vacation Marketing, 10, 308-319. https://doi.org/10.1177/135676670401000403

[41] Barquet, A., Brida, J.G., Osti, L. and Schubert, S. (2011) An Analysis of Tourists' Expenditure on Winter Sports Events through the Tobit Censorate Model. Tourism Economics, 17, 1197-1217. https://doi.org/10.5367/te.2011.0084

[42] Brida, J., Bukstein, D., Garrido, N. and Tealde, E. (2012) Cruise Passengers' Expenditure in the Caribbean Port of Call of Cartagena de Indias: A Cross-Section Data Analysis. Tourism Economics, 18, 431-447. https://doi.org/10.5367/te.2012.0115

[43] Marrocu, E., Paci, R. and Zara, A. (2015) Micro-Economic Determinants of Tourist Expenditure: A Quantile Regression Approach. Tourism Management, 50, 13-30. https://doi.org/10.1016/j.tourman.2015.01.006

[44] Hung, W., Shang, J. and Wang, F. (2012) Another Look at the Determinants of Tourism Expenditure. Annals of Tourism Research, 39, 495-498. https://doi.org/10.1016/j.annals.2011.09.006

[45] Chen, C. and Chang, K.L. (2012) The Influence of Travel Agents on Travel Expenditures. Annals of Tourism Research, 39, 1258-1263.

https://doi.org/10.1016/j.annals.2012.01.005 
[46] Huang, S. and Hsu, H. (2005) Mainland Chinese Residents' Perceptions and Motivations of Visiting Hong Kong: Evidence from Focus Group Interviews. Asia Pacific Journal of Tourism Research, 10, 191-205.

https://doi.org/10.1080/10941660500135977

[47] Brida, J. and Scuderi, R. (2013) Determinants of Tourist Expenditure: A Review of Microeconometric Models. Tourism Management Perspectives, 6, 28-40. https://doi.org/10.1016/j.tmp.2012.10.006

[48] Wang, Y., Rompf, P., Severt, D. and Peerapatdit, N. (2006) Examining and Identifying the Determinants of Travel Expenditure Patterns. International Journal of Tourism Research, 8, 333-346. https://doi.org/10.1002/jtr.583

[49] McGehee, N., Loker-Murphy, L. and Uysal, M. (1996) The Australian International Pleasure Travel Market: Motivation from a Gendered Perspective. Journal of Tourism Studies, 7, 45-57.

[50] Kim, C. and Lee, S. (2000) Understanding the Cultural Differences in Tourist Motivation between Anglo-American and Japanese Tourists. Journal of Travel and Tourism Marketing, 9, 153-170. https://doi.org/10.1300/J073v09n01_09

[51] Legoherel, P. and Wong, K. (2006) Market Segmentation in the Tourism Industry and Consumers' Spending: What about Direct Expenditures? Journal of Travel and Tourism Marketing, 20, 15-30. https://doi.org/10.1300/J073v20n02_02 